DISPOSAL OT RADIOACTIVE WASTES ${ }^{*}$

J. 0. Blomeke

Oak Ridge National Laboratory

Oak Ridge, Tennessee 37830

For presentation at seminar at

school of Nuclear Engineering, Texas A \& M University, College Sitation, Texas, November 5-9, 1979

\author{
By acceptance of this article, the \\ publisher or recipient acknowledgas \\ the U.S. Government's right to \\ retain a nonexclusive, royal ty-free \\ licensa in and to any copyright \\ covering the article.
}

\footnotetext{
*Research sponsored by the Office of Nuclear Waste Management, U.S. Department of Energy, under contract W-7405-eng-26 with the Union Carbide Corporacion.
} 


\section{DISPOSAL OF RADIOACTIVE WASTES *}

1. Introduction - DWG 79-1661. As discussed in Lecture 2, all of the principal types of radioactive wastes are generated in fuel reprocessing plants. Success in maneging those wastes should offer the key to handling the wastes from virtually all other sources. We have discussed the origin, nature and methods of treatment for these wastes. Today I would like to very briefly review the management approach, then devote the remainder of my tiule to a discussion of the disposal requirements options that are available.

2. Fuel Reprocessing Waste Management - DWG 70-1494.

\subsection{Gaseous waste management}

- Methods must be developed to immobilize ${ }^{3} \mathrm{H},{ }^{85} \mathrm{Kr},{ }^{129} \mathrm{I}$, perhaps ${ }^{14} \mathrm{C}$

- Storage of ${ }^{85} \mathrm{Kr}$ and ${ }^{3} \mathrm{H}$ for 1 to 2 centuries; ${ }^{129} \mathrm{I}$ and ${ }^{14} \mathrm{C}$ must be isolated, or diluted and dispersed

\subsection{LIquid wastes given multistep treatment}

\subsection{Solid wastes}

- TRU to repository; beta, gamma to land burial

- Compaction, incineration, and solidification methods are under development

\subsection{All types require packaging and shipment prior to disposal.}

3. Beneflcial Uses of Wastes. I would like to depart briefly to address an issue that is frequently raised whenever waste manageinent is discussed - that of the beneficial utilization of radioactive wastes. There are a wide variety of possible uses for many of the fission products and heavy-element isotopes found in the spent fuel from nuclear reactors. Many proposals have been made for using specific isotopes, the bulk solidified high-level wastes, and even the unprocessed spent fuel for heat and radiation sources. Also, some of the fission products have potential industrial value as mineral resources. From the standpoint of nuclear waste management, however, It must be kept in mind that the beneficial utilization of wastes or waste constituents does not represent an end in Itself, but must be considered as only another form of interim storage. The sharpness of the separations that are achievable by present technology is insufficient to permit materially altering the disposal requirements of the waste residuals; and, after the useful potential of the separated components has been realized, the requirements for their ultimate disposal likewise remain virtually unchanged. Finally, the large-scale recovery of specific constituents from wastes, preparation into forms suitable for use, and distribution over wide sectors of the country must be carefully assessed, since they have a number of adverse impacts on waste management.

* Research sponsored by the Office of Nuclear Waste Management, U.S. Department of Energy, under contract W-7405-eng-26 with the Union Carbide Corporation. 
3.1 Important considerat1ons - DWG 79-1662.

3.2 We conclude that any large-scale use of waste or waste constituents should be based on a detailed cost-risk-benefit analysis that considers the risk of radiation exposure to man In contrast to economic value of the particular beneficlal use and any additional costs to fuel reprocessing and waste management.

4. Interim Solld Storaje. Required for all transuranium wastes presently because final reposi ories have not been demonstrated. They are also needed for storage of spent fuels.

4.1 Sealed storage cask concept - DWG 74-6122. A "fa11-safe" concept for long-term (ulo0-year) storage.

4.2 Sealed cask storage array - DWG 74-6124. Casks placed on 25-ft centers would require 1000-1200 acres of land in year 2000 .

4.3 Air-cooled vault - DWG 74-6121.

4.4 Water basin - DWG 74-6123. Method currently in use for short-term ( $\leq 20$ years) use.

4.5 Low- and intermediate-level TRU wastes are non-heat-generating materials and are currently belng stored in varlous types of surface facilities at DOE sites pending resolution of a final isolation site.

5. Transportation. Radloactive materlals are shlpped only in solid forms, with the exception of minor quantities of ${ }^{\circ 5} \mathrm{Kr}$ and tritium. Hundreds of thousands of such shipments have taken place over the past 30 to 40 years without any serlous exposures to man and this is an unparalled record in the history of transporting hazardous materlals.

5.1 Low-level wastes. Shipped in unshlelded or lightly-shielded drums and crates by both rail and motor freight to shallow-land burlal grounds.

5.2 Hfgh-level waste cask (conceptual) - DWG 71-3841.

- 100 tons, 8 to 10 in. Pb or Fe, 4 to 6 in. $\mathrm{H}_{2} \mathrm{O}$

- Fing dissipate up to $40 \mathrm{~kW}$

5.3 Low-level TRU waste (15 mfllion $\mathrm{ft}^{3}$ exists; another 10 million expected by year 2000).

- Pelletized - DWG 70-9015

- ATIX car - PHOTO 99351. Welghs 60 tons, takes a 60-ton payload

5.4 Noble-gas shlpment cask (conceptual) - DWG 71-3839. 
6. Disposal Methods. The only wastes currently being disposed of are low-level wastes and tritium from resctors; all the other types are belng stored while final disposal optlons are being evaluated.

6.1 Low-level wastes are d1sposed of in shallow-land burial grounds or at Oak Ridge National Laboratory by hydrofracturing into a shale formation several hundred feet below the surface.

" Location of burial sites - DWG-12267. Six commercial sites, however only Barnwell, Beatty, and Richland are in operation. Others have been closed because of public concern over their operations.

- Photo of burial trench - PHOTO 97988. Over 50 million $\mathrm{ft}^{3}$ DOE waste and 16 million $\mathrm{ft}^{3}$ of commercial waste have been buried using about 1000 acres of land. By the year 2000, the land requirements will be more than doubled if present burfal techniquee are continued.

- Hydrofracturing - DWG 63-3830. In use at ORNL and can be applied to pelletized solids.

6.2 Other disposal methods in use or under development for low- and Intermediate-level wastes

- Excavated caverns - PHOTO 4099-78

- Disposal in Germany - PHOTO 1192-74

- Disposal in matrix holes - PHOTO 4098-78. For LL or LL TRU wastes

- Disposal in solution-mined cav1ty - DWG 76-12Rl. Proposed for direct disposal of low- and intermediate-level wastes by Germany

6.3 Higi-level and low-level TRU wastes are the greatest challenge because of their heat dissipation and their very long-term isolation requirements.

6.3.1 Possibllitles for long-term storage/disposal - DWG 74-12661R1. Storage implies easy retrleval; disposal implies retrieval with difficulty, if at all. Disposal in geologic formations using conventional mining techniques is considered to be the best near-term option.

6.3.2 Locations of major geologic formations of interest.

- Salt deposits - OWI-76-25

- Argillaceous formations - DWG 74-1641

- Crystalline and rolcanic rocks - DWG 75-17300

6.3.3 Advantages of salt formations for disposal - LR-DHG 61939RI

- Proposed location of Waste Isolation Pilot Plant (WIPP) in New Mexico - DWG 73-69RI

- Concept of repository - DWG 73-924

- Photo of excavations in salt - PHOTO 3274-75. 
7. Pregent U.S. RDED Program in Watte Isolation

- DOE Waste Isolation Program Elements - DWG 79-627

- WIPP - DWG 79-628

- Pasco Basin Basalt - DWG 79-629

- Nevada Teat Site - DWG 79-630

- ONWI Program - DWG 79-63I

- Forelgn Prograns - DWG 79-632 
SOURCES OF RADIOACTIVE WASTES

\section{FUEL PREFARATION REACTOR AND FABRICATION \\ FUEL REPROCESSING}

SPENT FUEL

$x$

TRANSIRANIUM

HIGH-LEVEL

CLADDING HULLS

INT. - LEVEL

LOW-LEVEL

$x$

$x$

$x$

$x$

$x$

NON-TRANSURANIUM

NOBLE GASES $\left({ }^{85} \mathrm{~K}_{R}\right)$

IODINE (129 I)

$x$

$x$

CARBON-14

$x$

$x$

TRITIUM

LOW-LEVEL

$\begin{array}{ll} & x \\ x & x \\ x & x \\ x & x\end{array}$



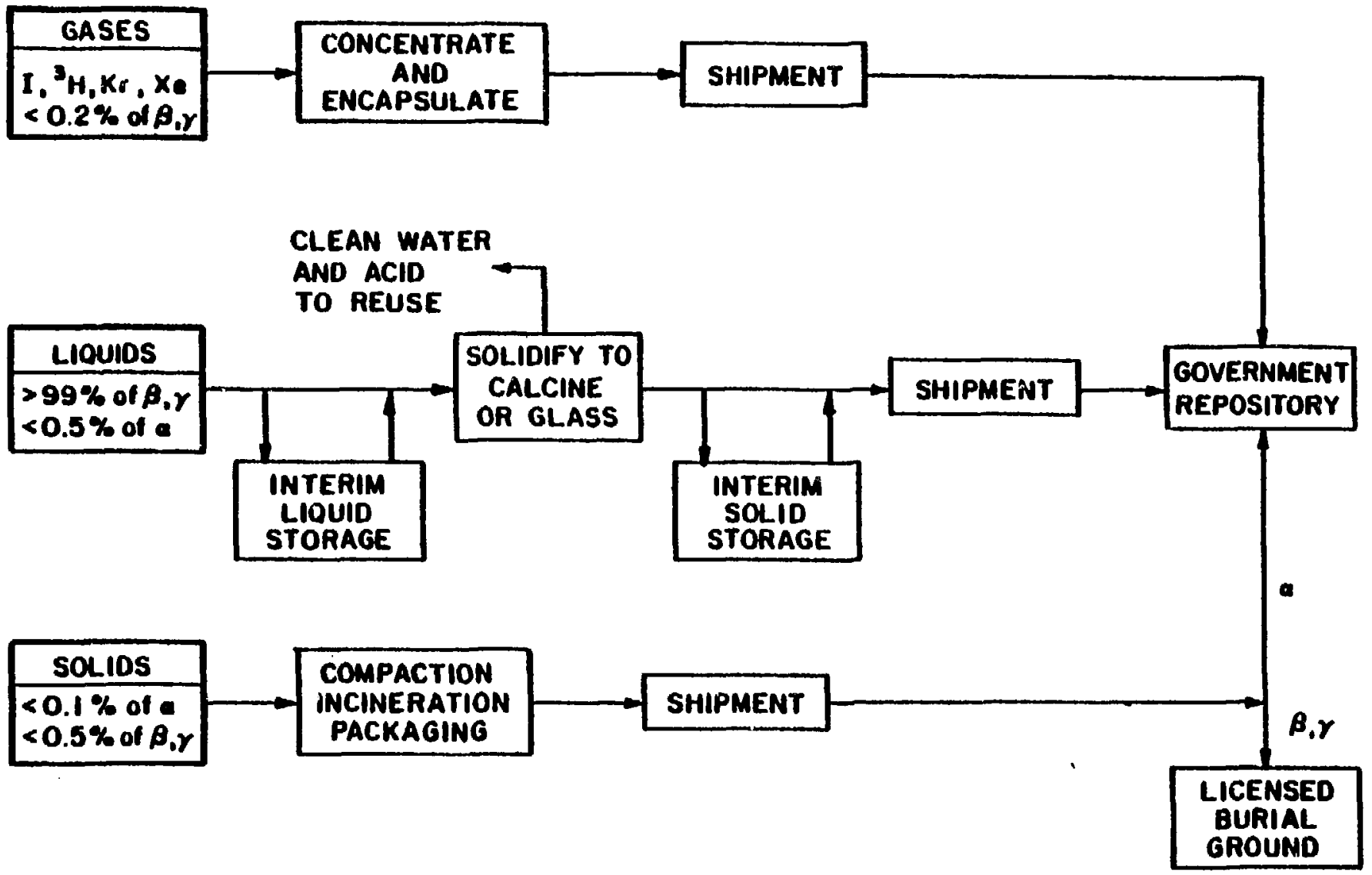

MANAGEMENT OF WASTES FROM REPROCESSING SPENT FUELS 


\section{CONSIDERATIONS RELATIVE TO BENEFICIAL USE OF WASTE CONSTITUENTS}

1. INCREASED GENERATION OF SECONDARY WASTES

2. INCREASED TRANSPORTATION REQUIREMENTS

3. INCREASED RISK OF RADIATION EXPOSURE

4. INCREASED ACCOUNTABILITY REQUIREMENTS

5. UNCERTAIN ECONOMICS 


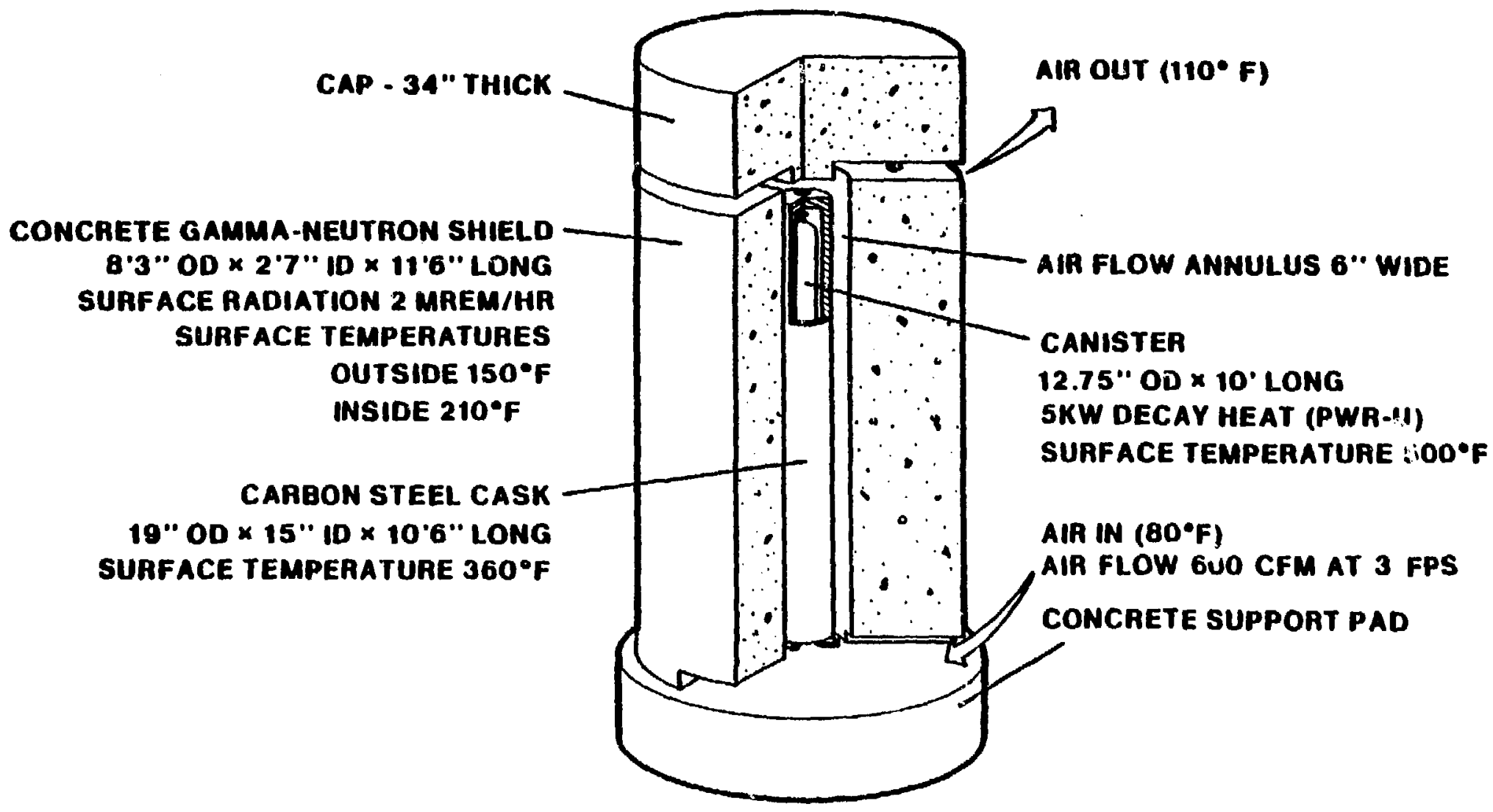

SEALED STORAGE CASK CONCEPT 


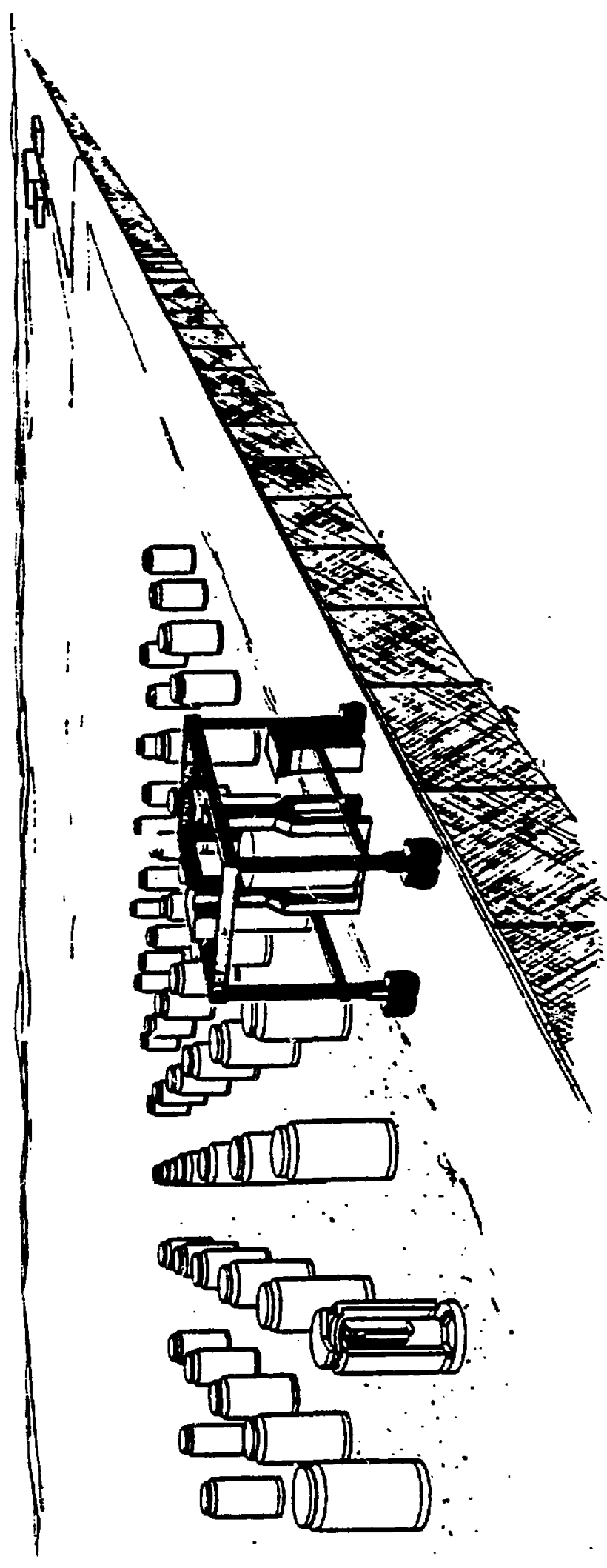

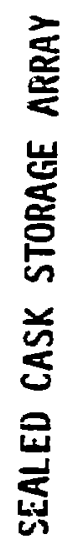




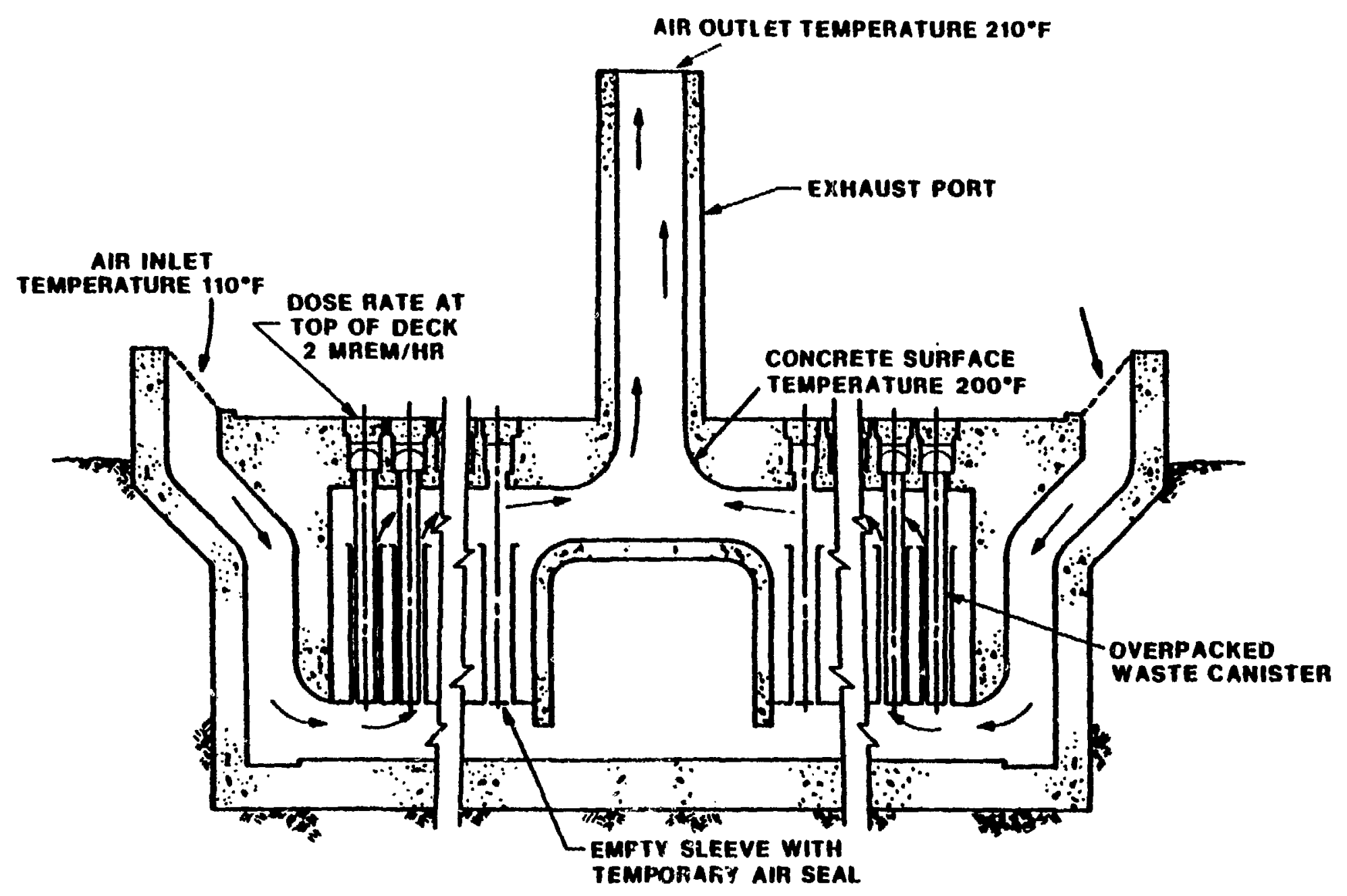

AIR-CCOLED VAULT CONCEPT 


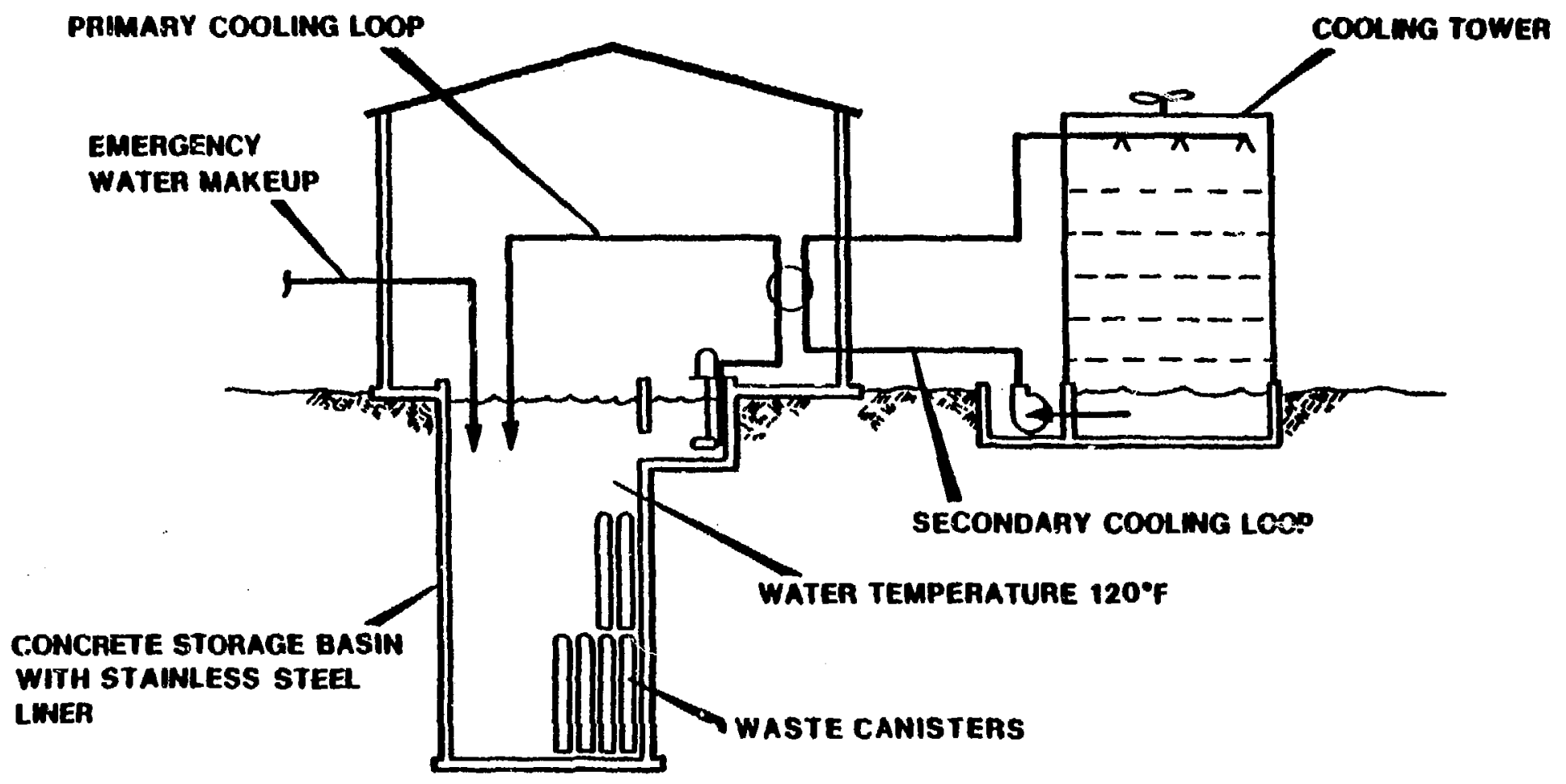

WATER BAIIN CONCEPT 

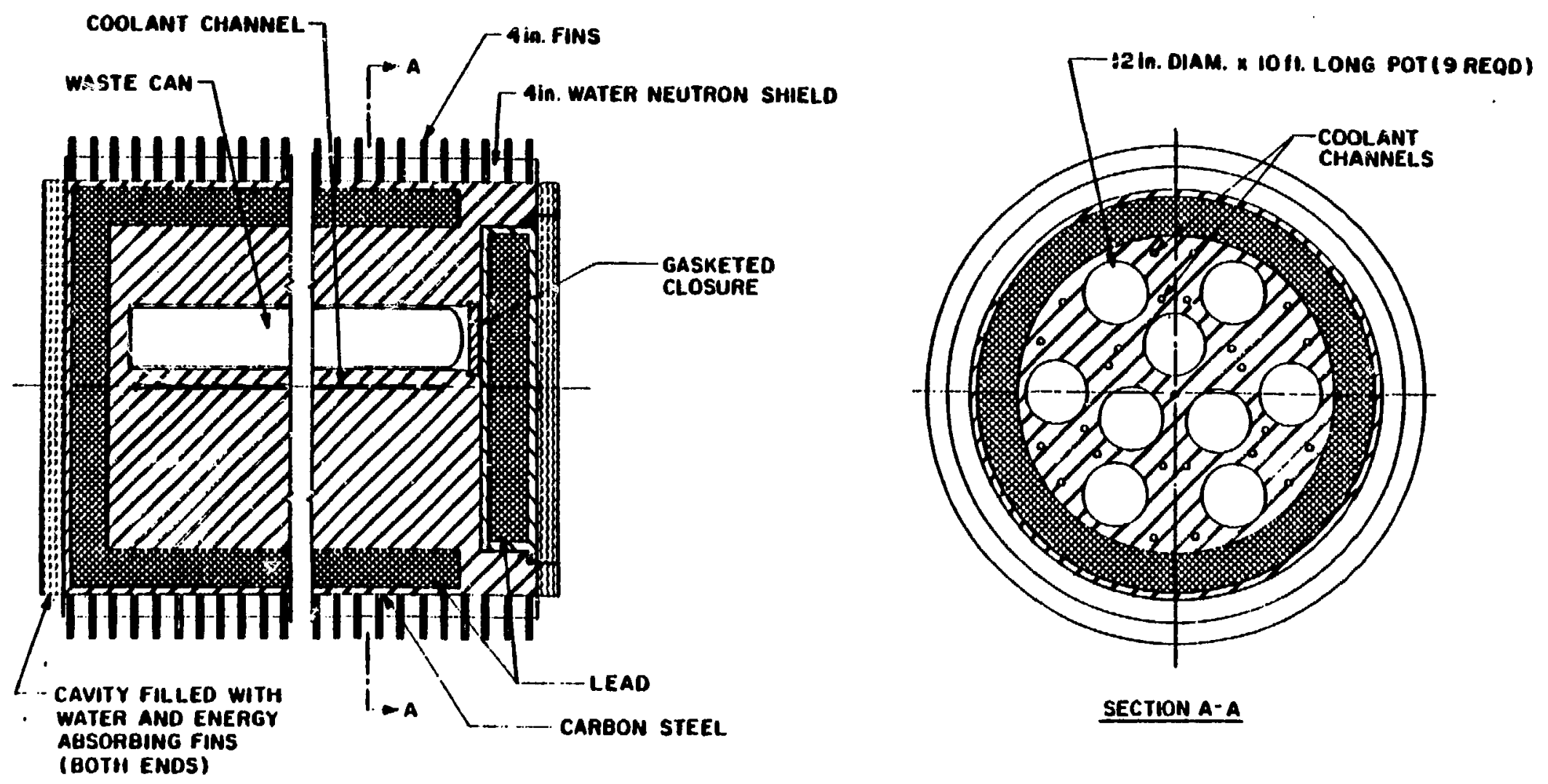
ORNL DWG 70-9015

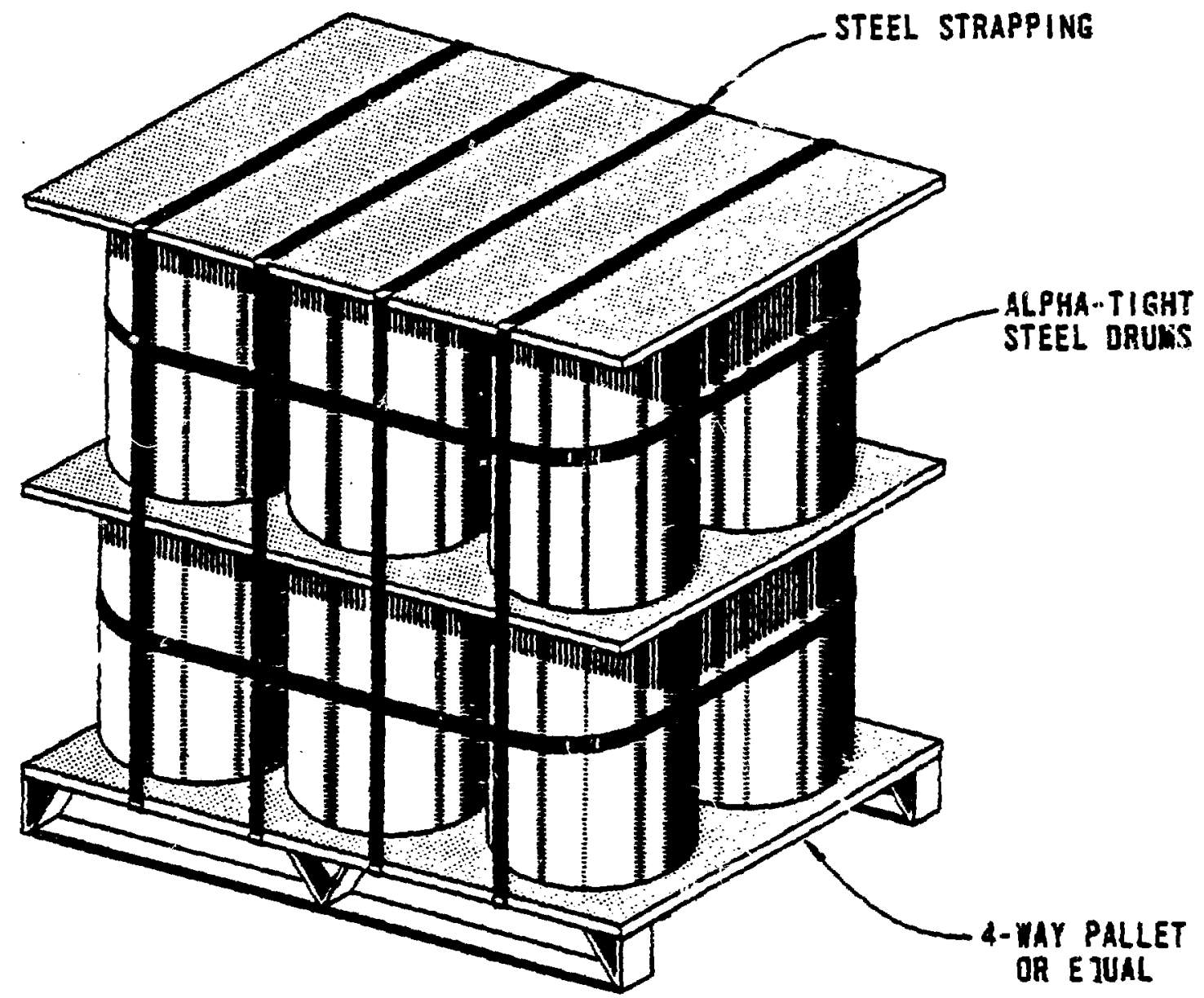

12 ORUM ALPHA BURIAL UNIT

$(4 \times 6 \times 6$ FT NOMINAL OVERALL) 


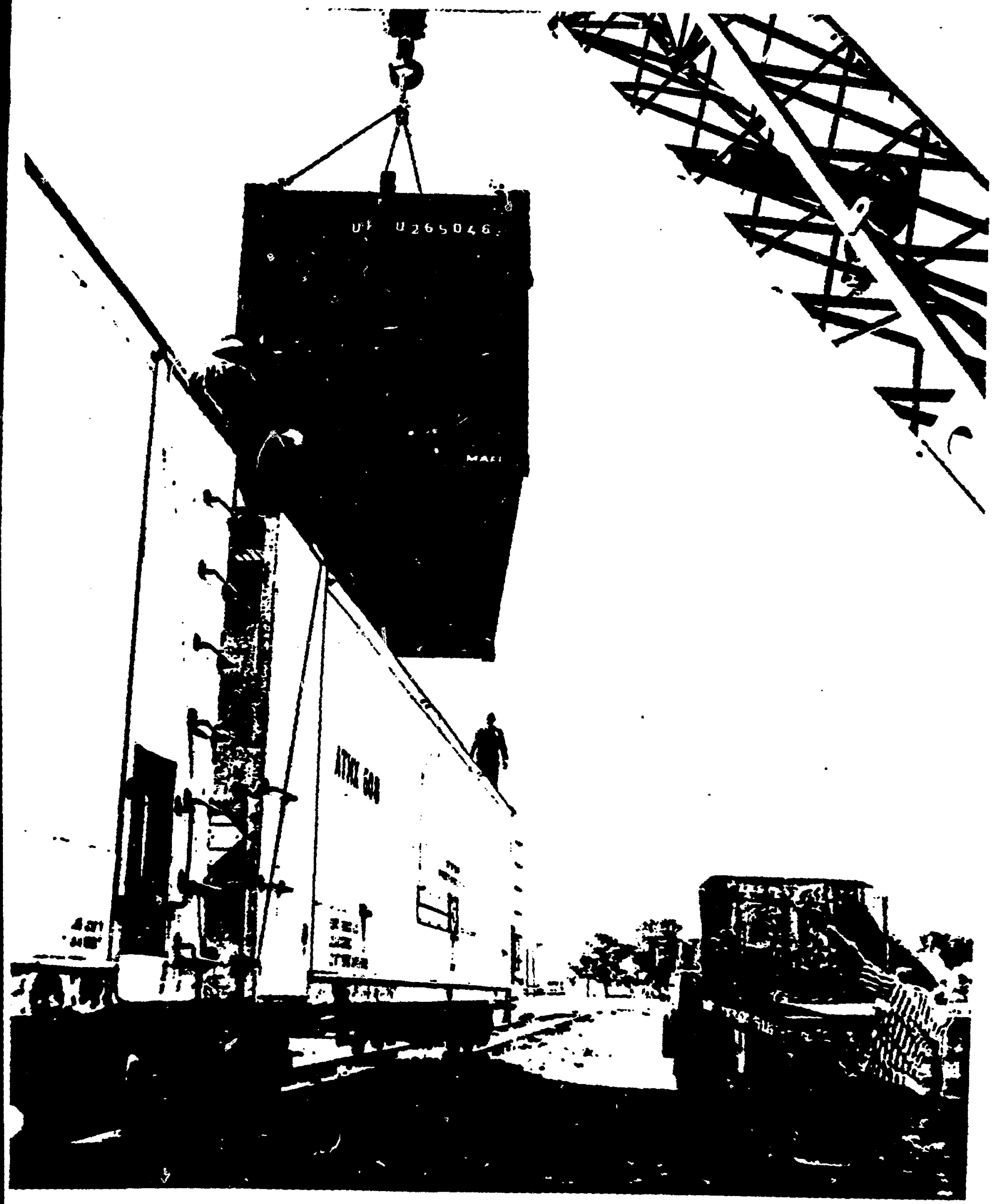


ORNL - ONG - 7L-3839

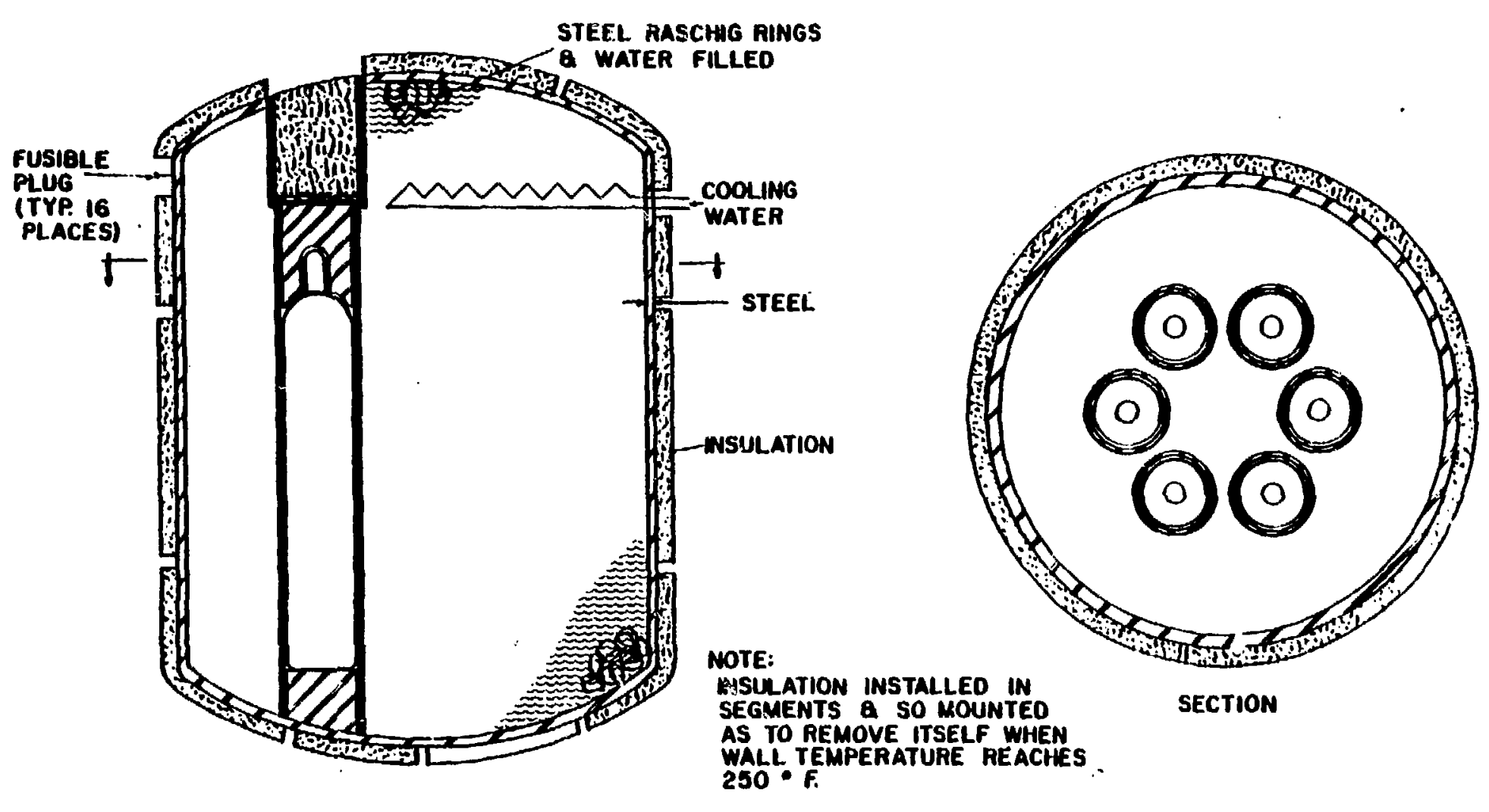




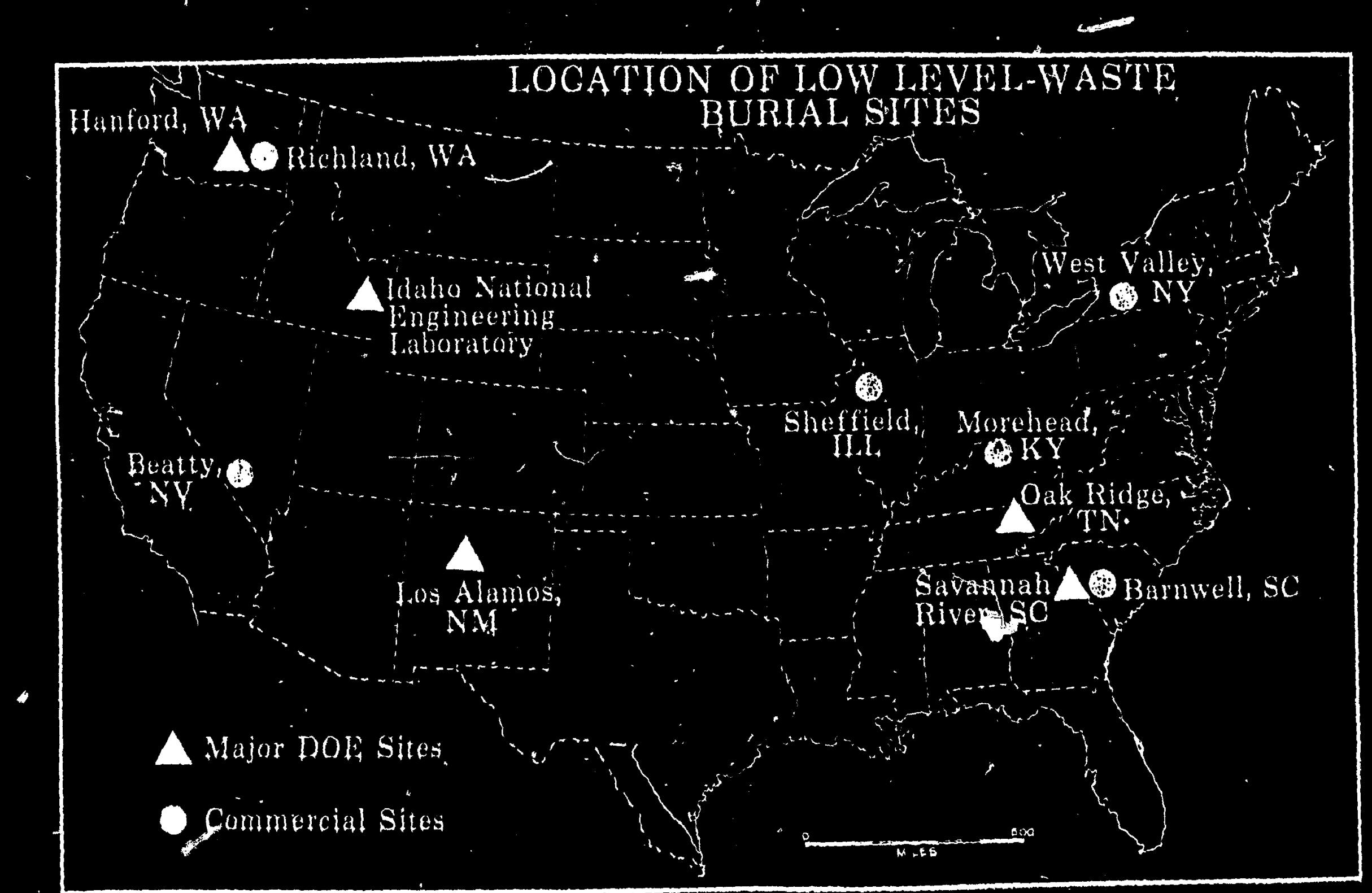




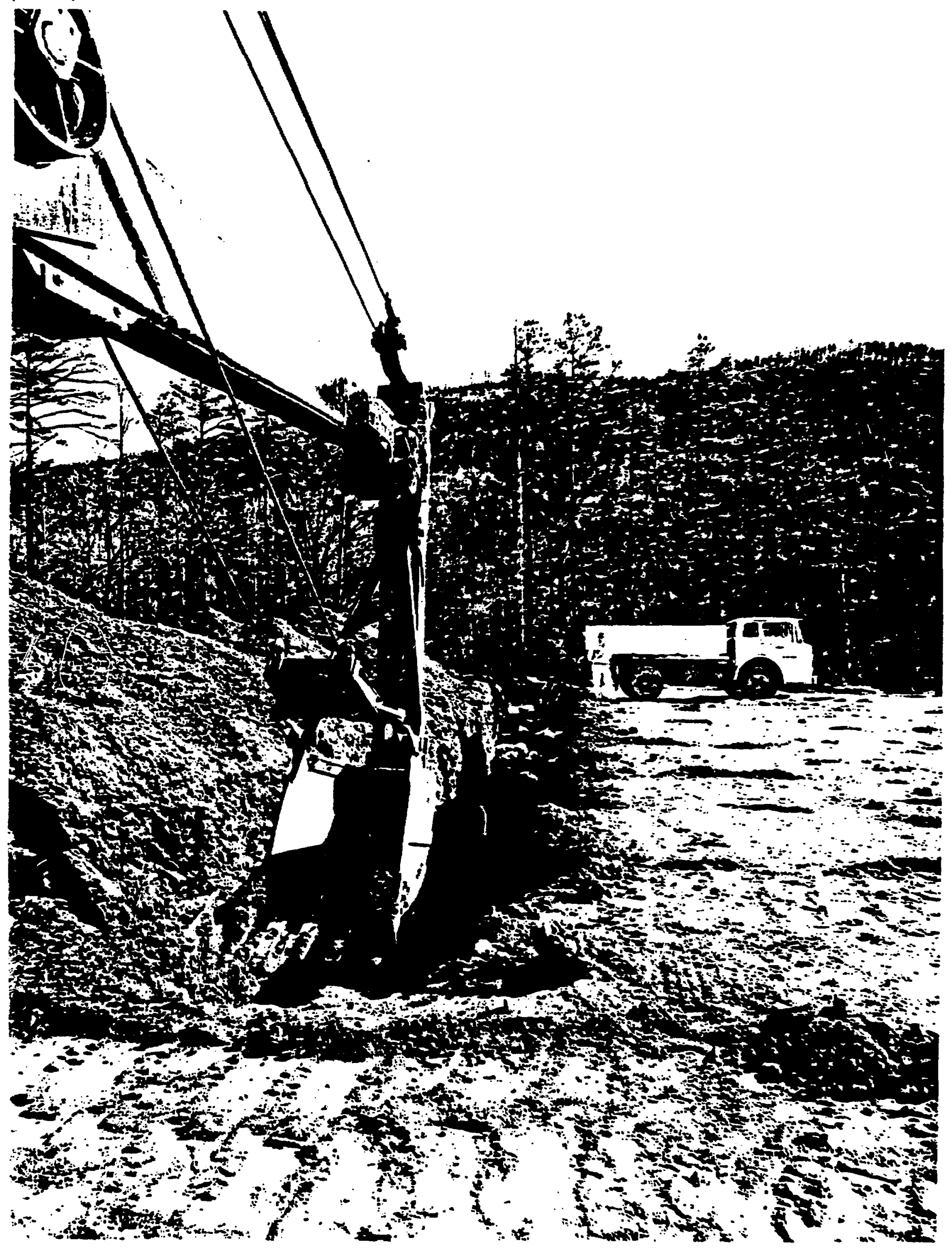




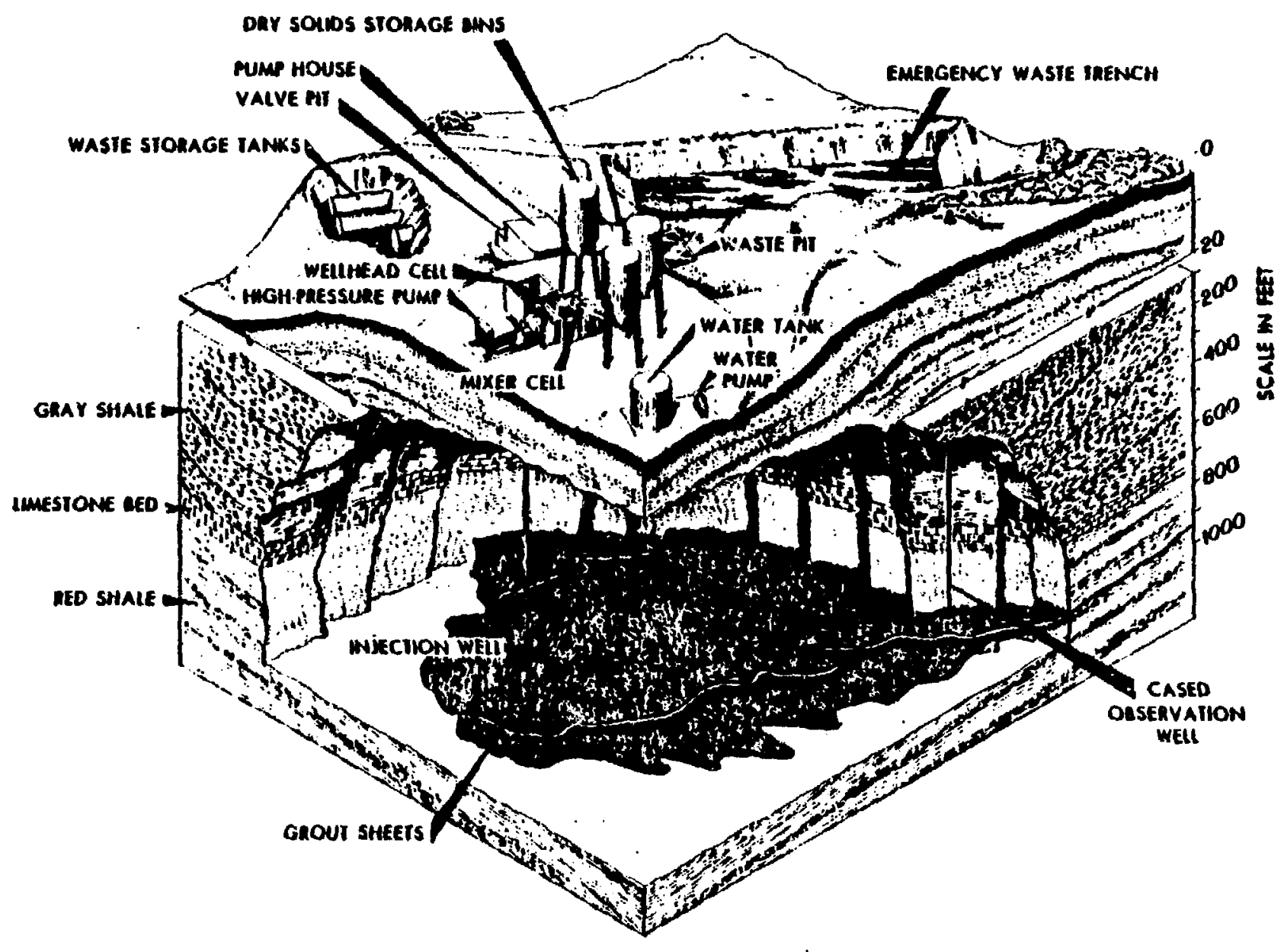

ORNL FRACTURING DISPOSAL PILOT PLANT 


\section{EXCAVATED-CAVERN DISPOSAI OF LOW-LEVEI WASTES IN DRUMS}

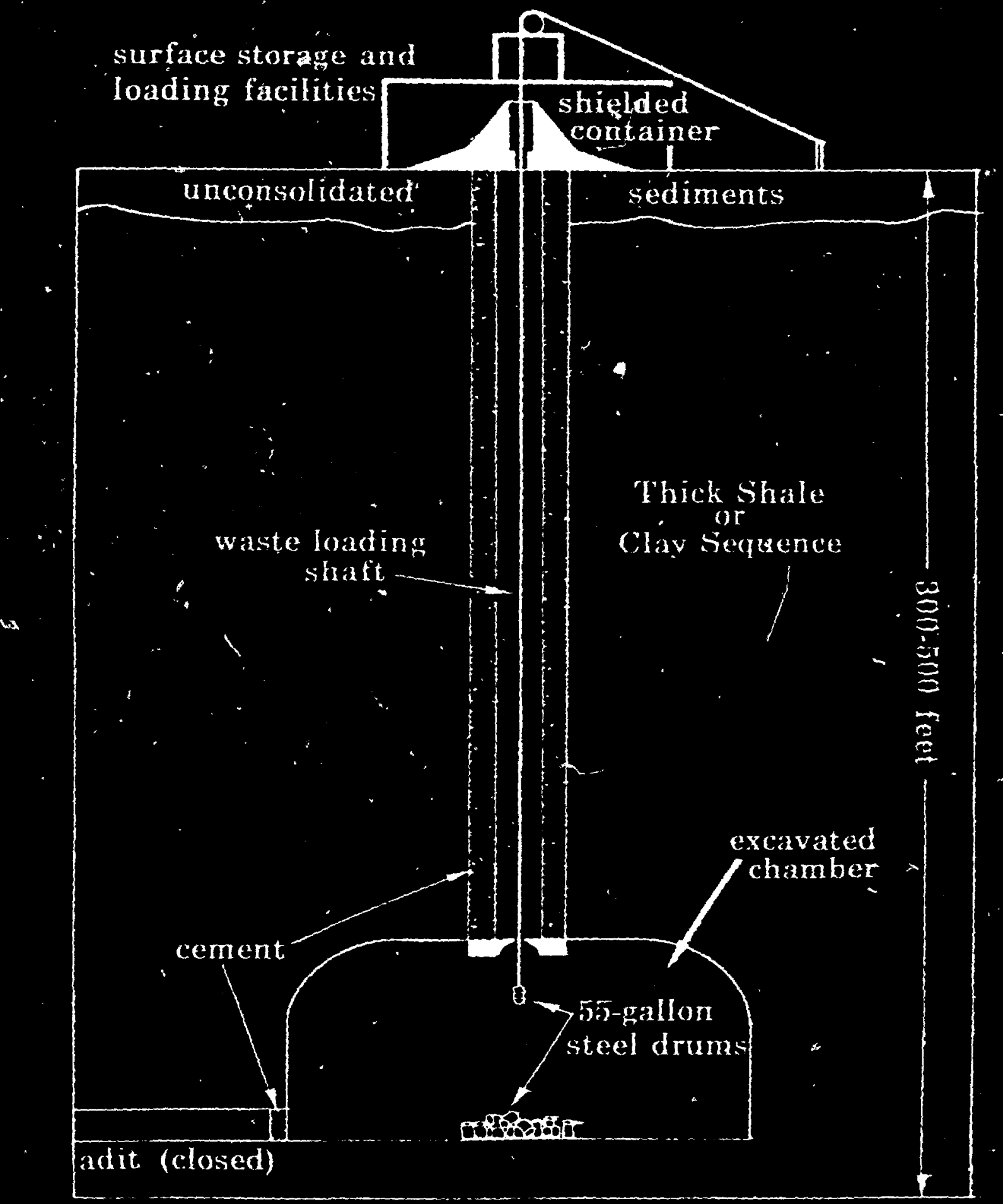




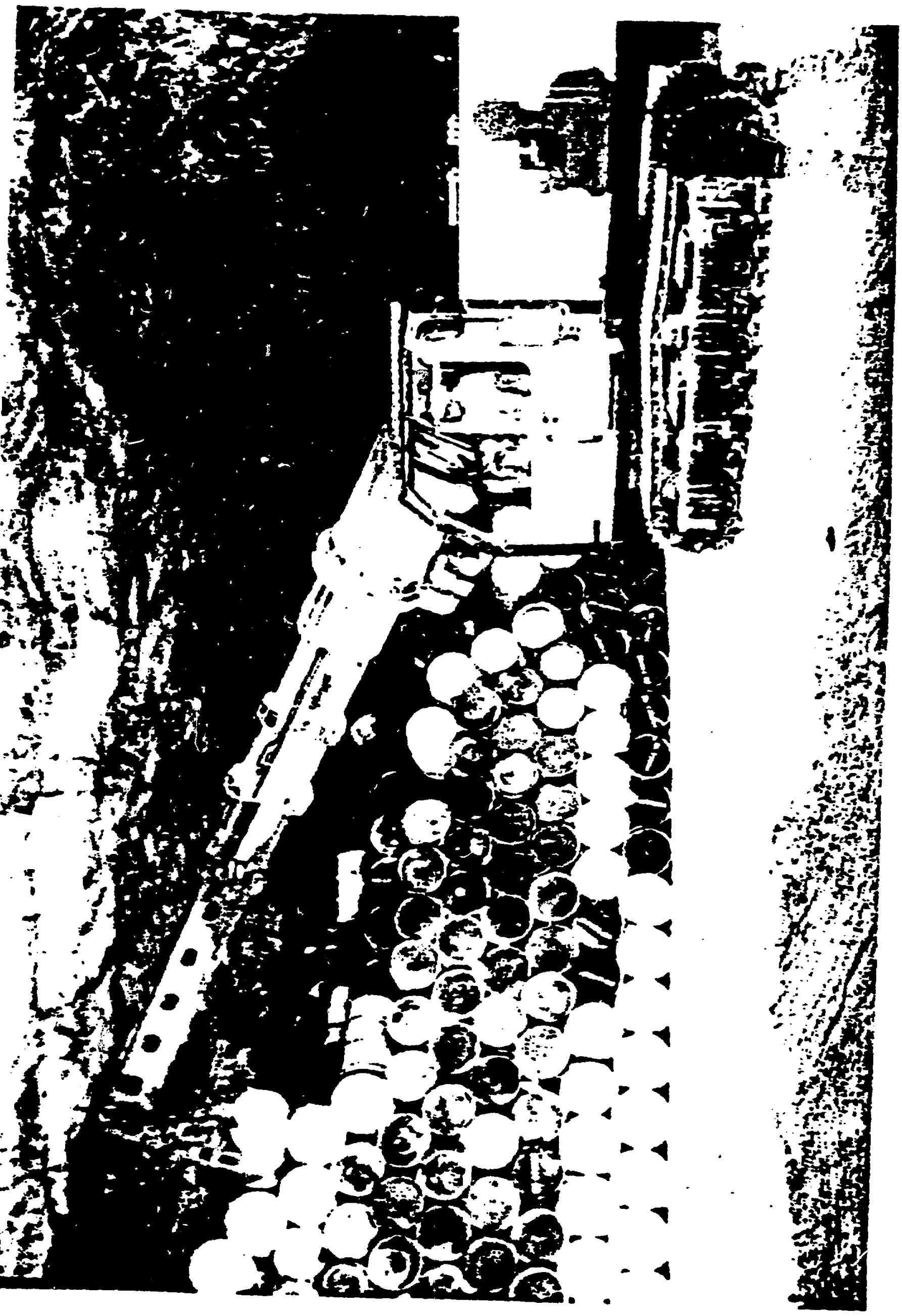




\section{RETRIEVABIE SEALED-WEIL DISPOSAL}

OF LOW-LEVEI WASTES IN DRUMS

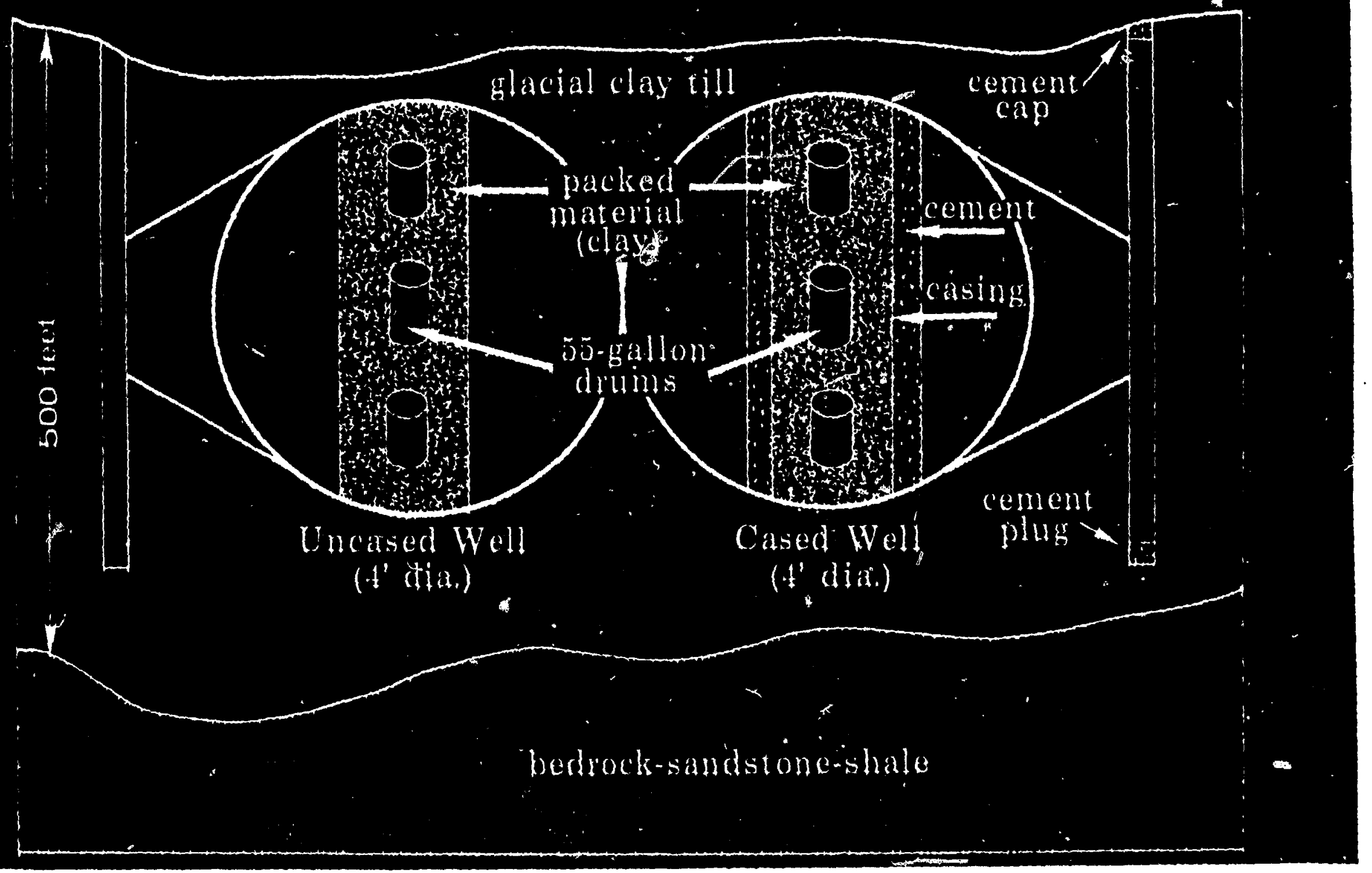


and and rant

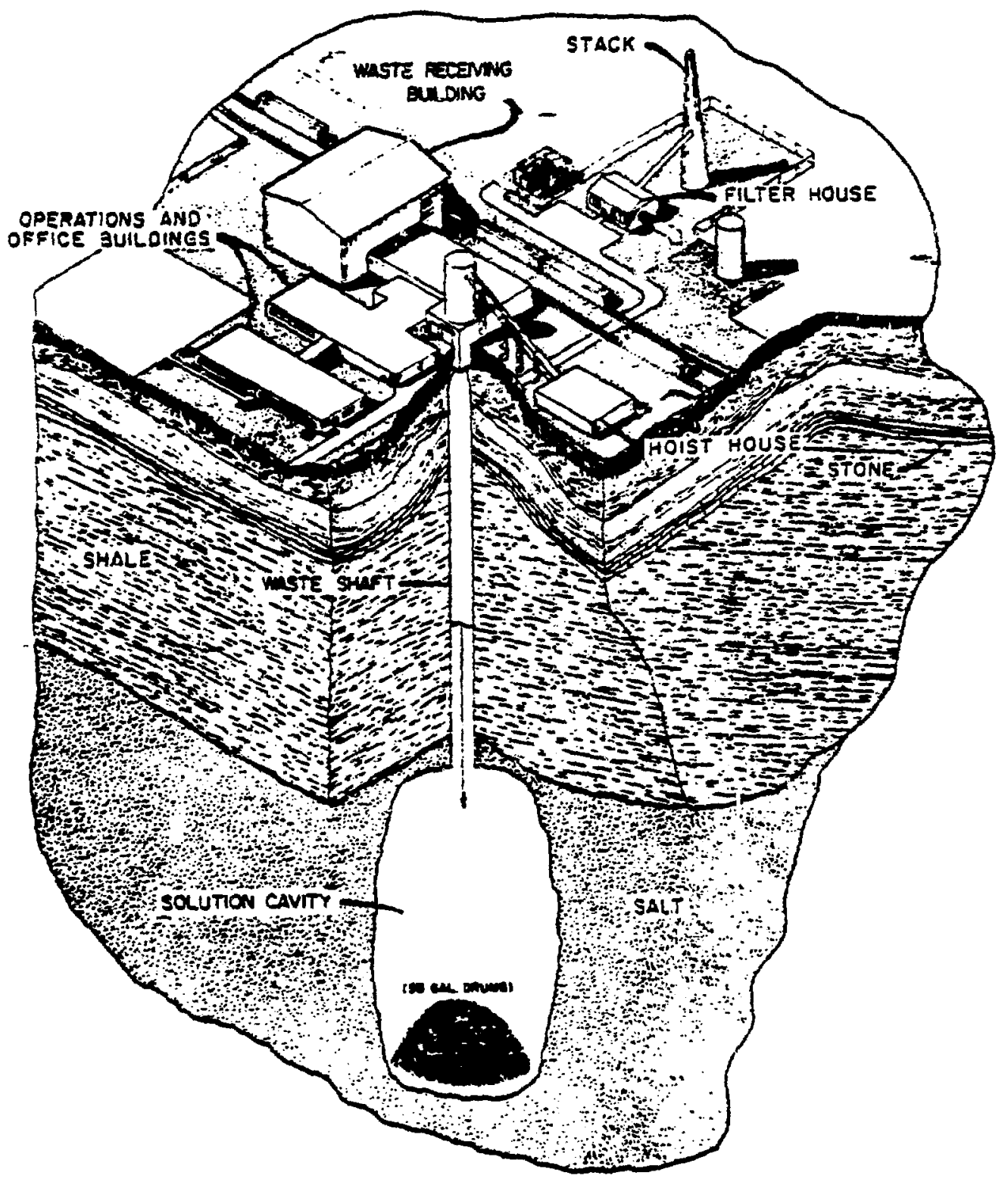

GENERALIZED CONCEPT

SOLUTION MINING FINAL STORAGE FACILITY 
POSSIBILITIES FOR LONG-TERA STORAGE AND DISPOSAL

1. ISOLATION ON EARTH

STORAGE AS LIQUIDS IN TANKS

STORAGE AS SOLIDS IN CONCRETE STRUCTURES

DISPOSAL AS SOLIDS IN CRYSTALLINE ROCKS

DISPOSAL AS SOLIDS IN SIIALES AND CLAYSTONES

DISPOSAL AS SOLIDS IN SALT FOREMTIONS

DISPOSAL AT GREAT DEPTHS UNDERGROUND

DISPOSAL AT SEA

DISPOSAL HITHIN POLAR ICE CAPS

2. TRANSINUTATION TO NONRADIOACTIVE SPECIES

3. DISPOSAL INTO OUTER SPACE 


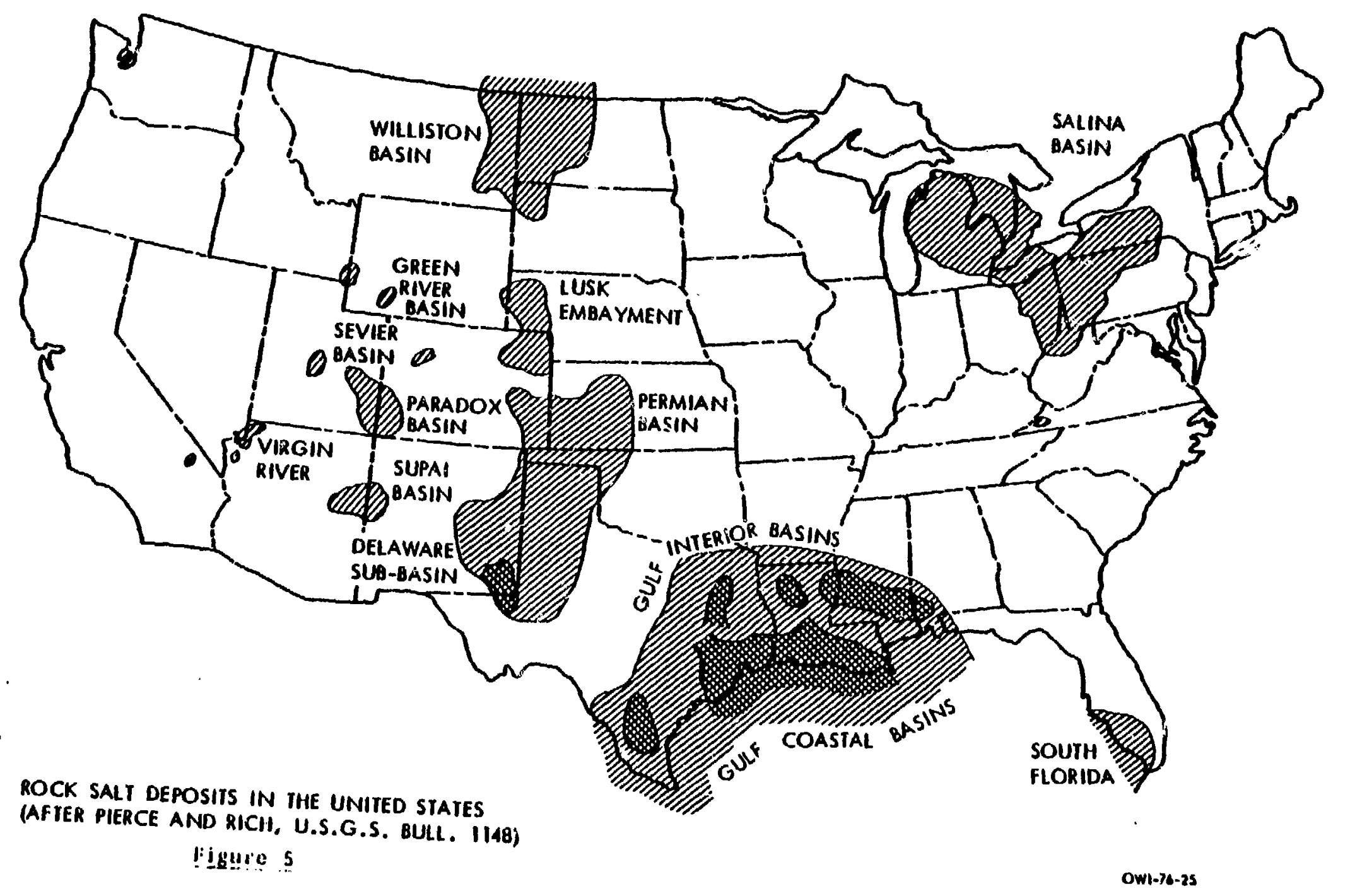




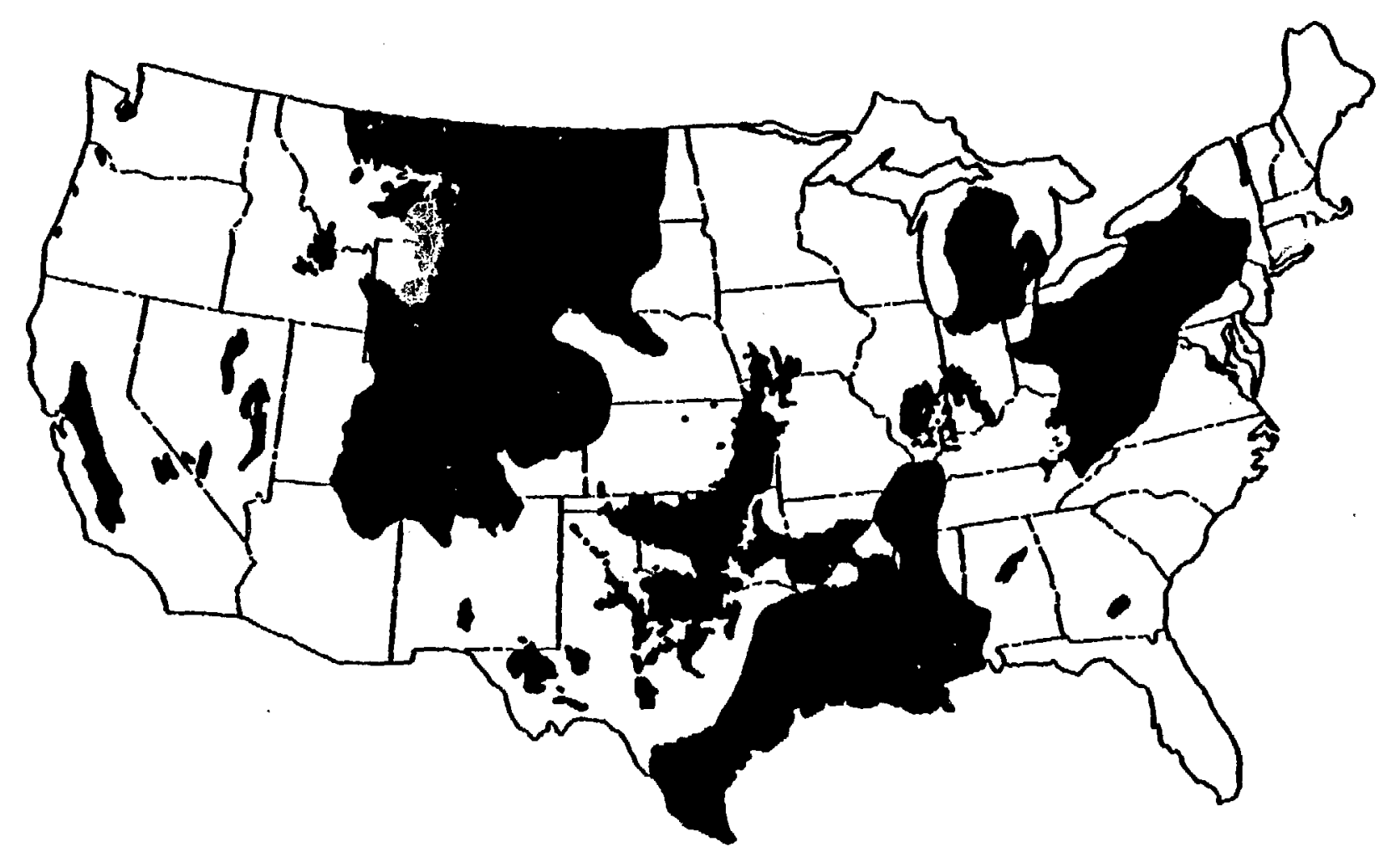

Thick Bodies of Shale, Mudstone, and Claystone in the U.S. 


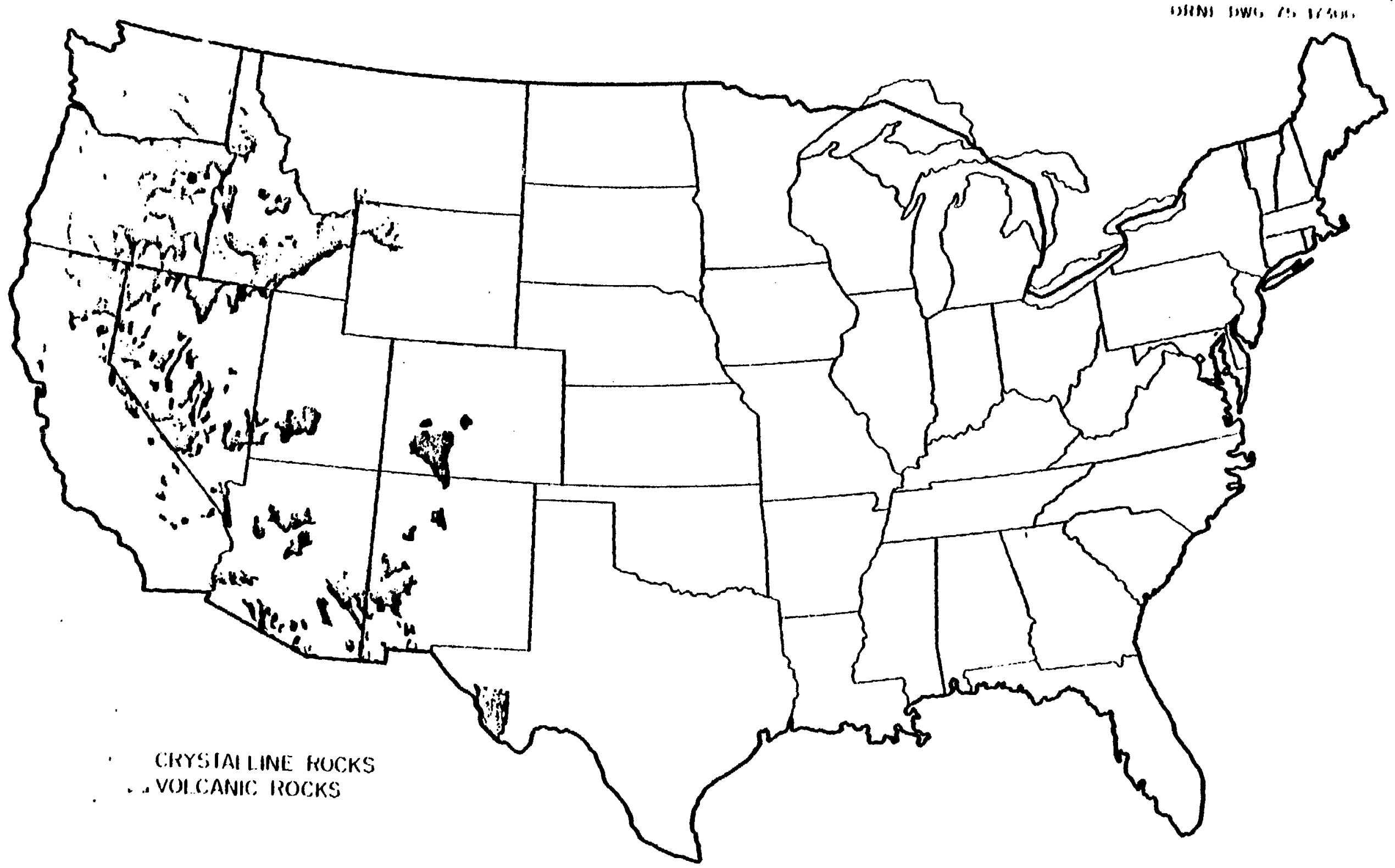

Crystalline and Volcanic Rocks in the U.S. 


\section{ORNL-LR-DWG 61939 RI}

ADVANTAGES OF SALT FORMATIONS FOR STORAGE OF RADIOACTIVE WASTES

1. ESSENTIALLY IMPERMEABLE

2. WIDESPREAD AND ABUNDANT

3. HIGH STRUCTURAL STRENGTH

4. LOW COST OF DEVELOPING SPACE

5. GOOD THERMAL CONDUCTIVITY

6. LOCATED IN AREAS OF LOW SEISMICITY 
ORNL DWG. 73.69 RI
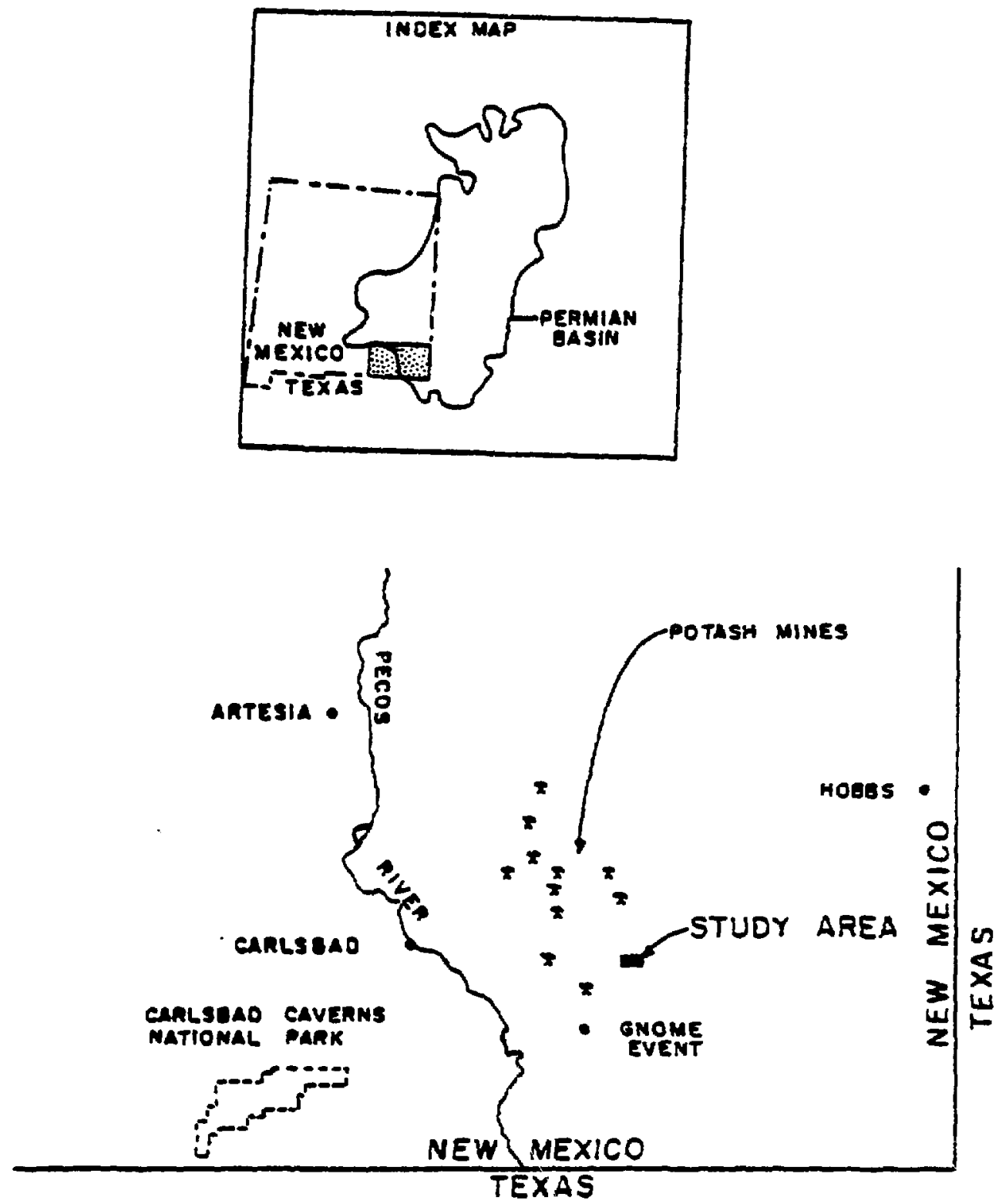

O $10 \quad 20 \quad 30$ MILES

LOCATION MAP 


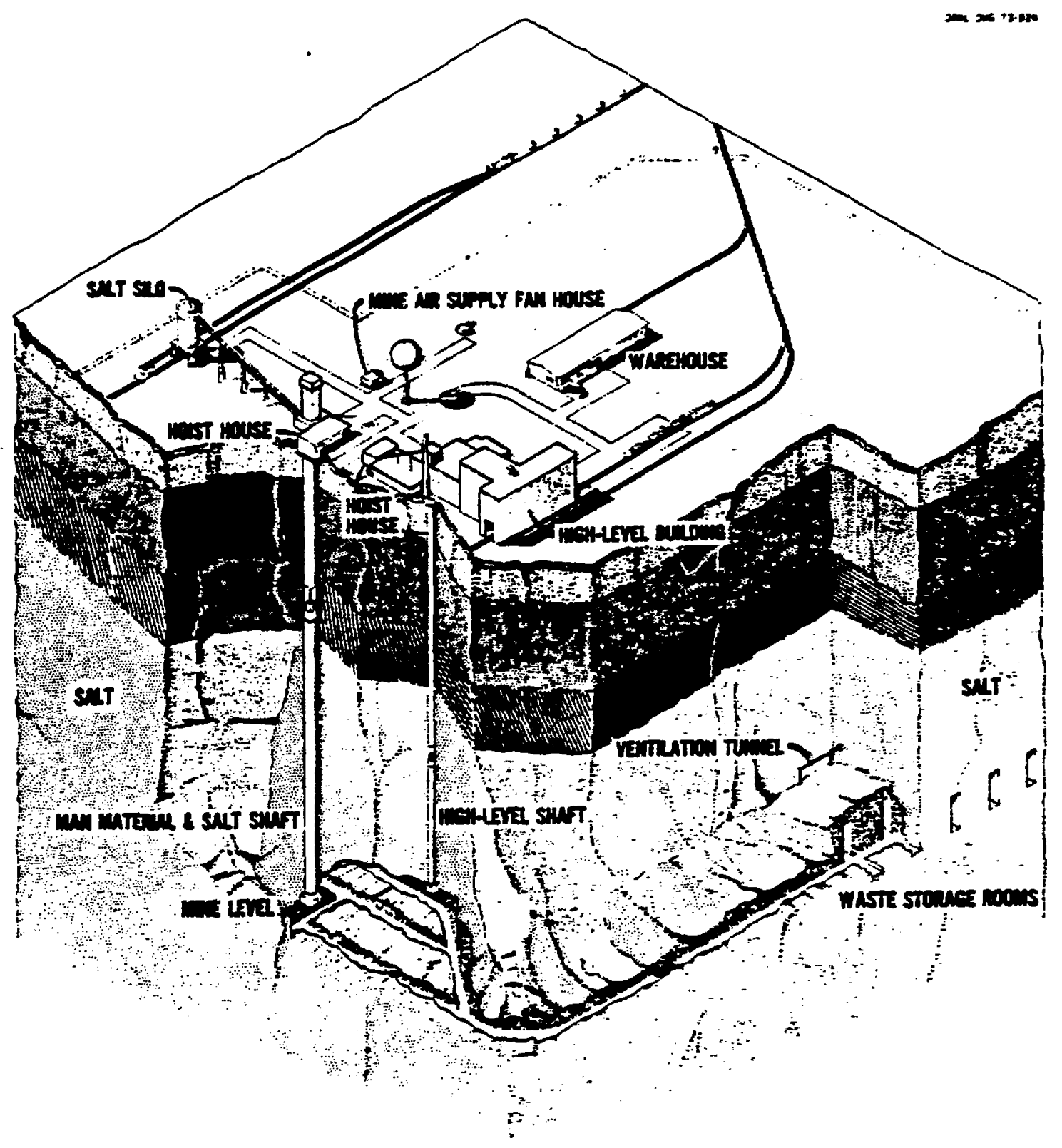

PLOT PLANT REPOSITORY 


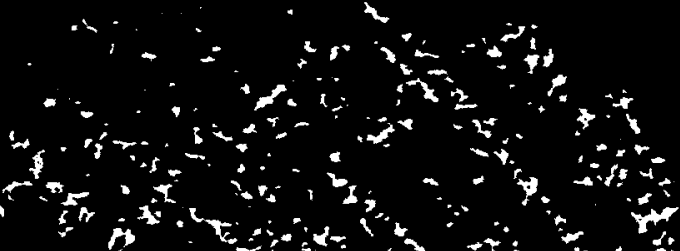

intor

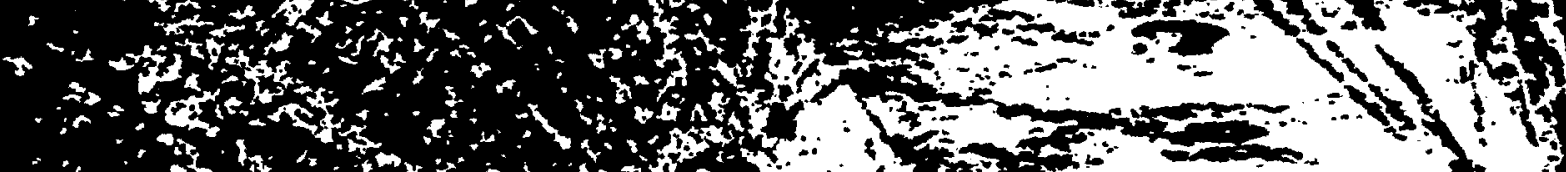
s

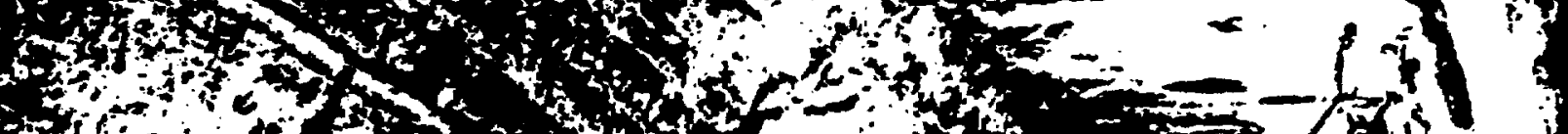

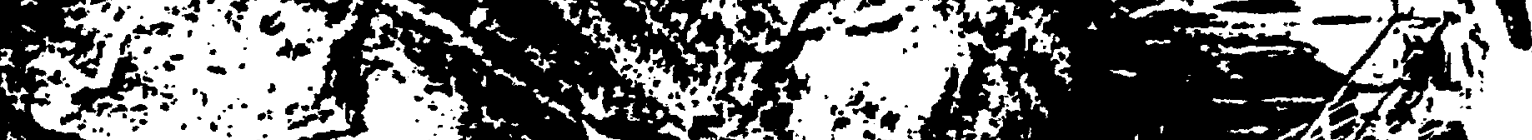

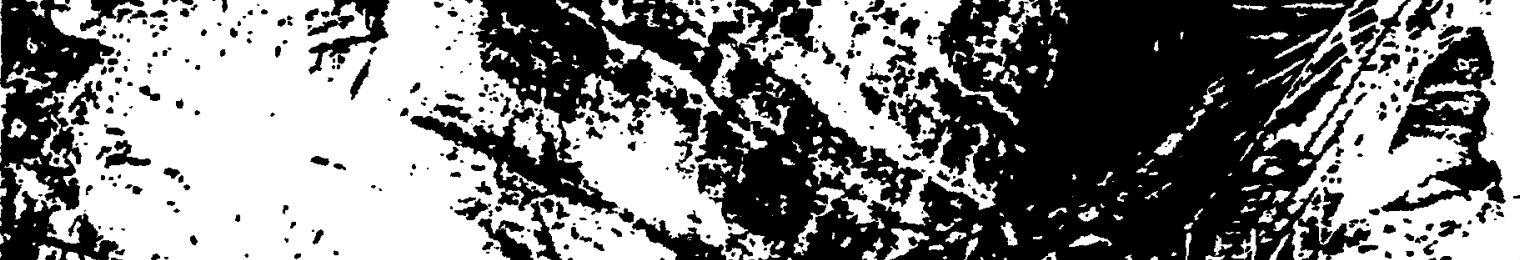

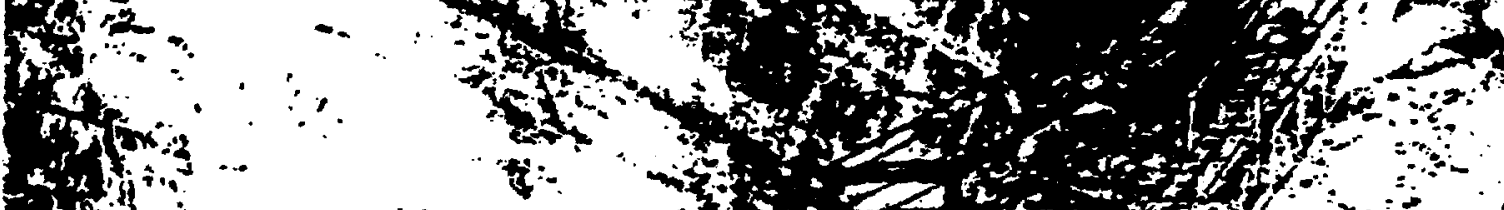

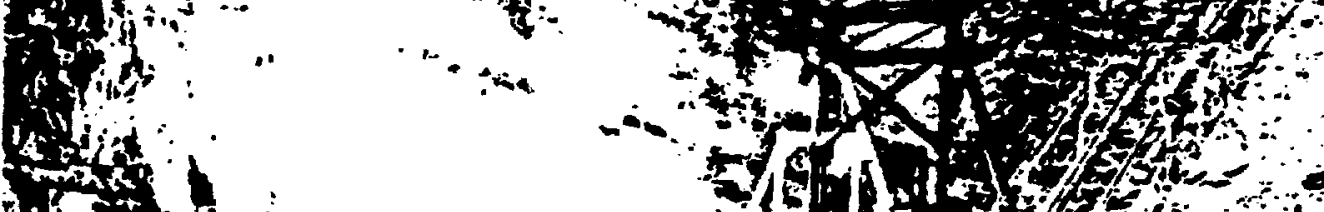

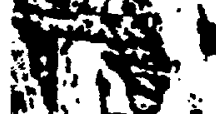

A.

$-4 x+4=1$

tritis

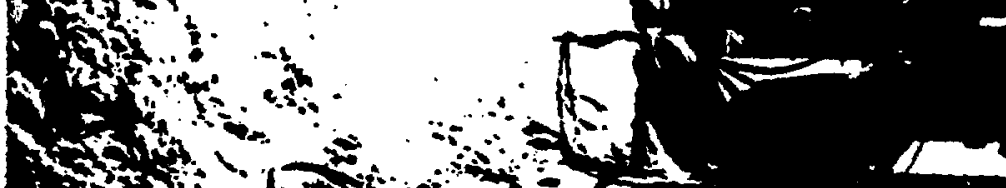

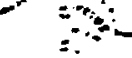

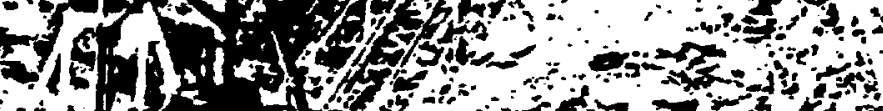

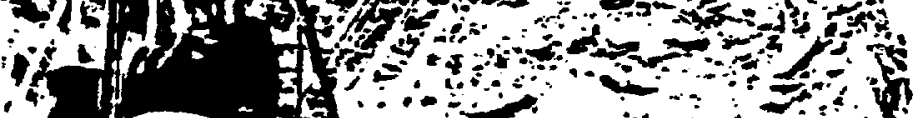


ORIIL DWG 79-627

\section{DOE WASTE ISOLATION PROGRAM ELEMENTS}

- WIPP (WASTE ISOLATION PILOT PLANT)

- pasco basin basalt

- NEVADA TEST SITE

- ONWI (OFFICE OF NUCLEAR WASTE ISOLATION) 
ORNL IWG 79-628

\section{WIPP}

- RESPONSIBILITY: SANDIA, BECHTEL, WESTINGHOUSE

- MISSION: DEFENSE TRU WASTES, HLW EXPERIMENTS, PROPOSED SPENT FUEL STORAGE

- StATUS: SITE SELECTED IN BEDDED SALT 2200 FT BELOW SURFACE

- SCHEDULE: OPERATIONAL IN 1985/86 
ORNL DWG 79-629

\section{PASCO BASIN BASALT}

- RESPONSIBILITY: ROCKWELL-HANFORD

- MISSION: COMMERCIAL SPENT FUEL OR HLW BUT HAS OBVIOUS APPLICABILITY FOR HANFORD DEFENSE WASTES

- STATUS: EXTENSIVE SITE INVESTIGATIONS; CONSTRUCTION UNDERWAY ON USTF (5000-FT TUNNEL SYSTEM) FOR TEMPERATURE AND MATERIALS TESTING

- SCHEDULE: OPERATIONAL IN 1990/92 
ORNL DWG 79-630

NEVADA TEST SITE

- RESPONSIBILITY: SANDIA, LIVERMORE

- MISSION: COMMERCIAL SPENT FUEL AND HLW STORAGE/DISPOSAL

- STATUS: FIELD TESTS/INVESTIGATIONS OF GRANITE, ARGILLITE, TUFF, AND ALLUVIUM HAVE NOT SHOWN EXPECTED PROMISE TO-DATE

- SCHEDULE: UNCERTAIN 
ORNL DWG 7y-631

\section{ONWI}

- RESPONSIBILITY: BATTELLE MEMORIAL INSTITUTE

- MISSION: COMMERCIAL SPENT FUEL, HLh, TRU WASTES IN SALT, SHALE, AND GRANITE

- STATUS AND SCHEDULE

- SITE SELECTED IN SALT DOME IN 1981

- SITE SELECTED IN PARADOX BASIN SALT IN 1983

- SITE SELECTED. IN PERMIAN BASIN SALT IN 1983

- SITE SELECTE IN SALINA BASIN SALT IN 1984/85

- EFFORT INCREASING ON SHALE AND GRANITE 
ORNL DHG 79-632

\section{FOREIGN PROGRAMS}

- WEST GERMANY

- OPERATING LLW REPOSITORY IN SALT

AT ASSE

- PROPOSED LLW-HLW REPOSITORY IN SALT AT GORLEBEN

- SWEDEN - DESIGN/TESTING STUDIES OF GRANITE

- UK - HEATING TESTS IN GRANITE

- CANADA - DEVELOPMENT STUDIES IN GRANITE AND SALT

- BELGIUM - STUDIES OF CLAY DEPOSITS

- EAST GERMANY - OPERATING LLW REPOSITCRY IN SALT

- USSR - APPARENTLY STUDYING SALT DEPOSITS 